\title{
SOVIET INHERITANCE CASES IN AMERICAN COURTS AND THE SOVIET PROPERTY REGIME
}

\author{
W. Reece Bader, * Peter O. Brown,** \\ and Kazimierz GrzybowsKi†
}

Many American states have statutes limiting transmission of monies from estates in this country to citizens of countries behind the "Iron Curtain." American courts have come under heavy criticism for construing these statutes unfavorably to foreign heirs, especially where transmission to heirs in the Soviet Union is withheld. This article analyzes the relevant American and Soviet law and concludes that American courts, while they have not always been completely objective, nevertheless may be justified in withholding distribution from Soviet citizens.

\section{INTRODUCTION}

All the known facts of a Sovietized state lead to the irresistible conclusion that sending American money to a person within the borders of an Iron Curtain country is like sending a basket of food to Little Red Ridinghood in care of her "grandmother."

A NUMBER of American courts, using language similar to that $\mathrm{A}_{\text {used by Justice Musmanno in the passage quoted above, have }}$ refused to permit distribution of funds from American estates to beneficiaries living within the confines of the Soviet bloc, particularly to those living in the Soviet Union itself. ${ }^{2}$ Such decisions

\footnotetext{
* B.A. 1963, Williams College. Student, Duke University School of Law.

* B.A. 1962, Amherst College; LL.B. 1965, Duke University. Member, New York Bar.

†LL.M. 1931, Doctor of Law and Political Science 1934, University of Lwow (Poland); S.J.D. 1933, Harvard University. Senior Research Associate of the Rule of Law Research Center and Lecturer in Law, Duke University. Author, Soviet PRIVATE International Law (Law in Eastern Europe No. 10, 1965), The Socialist CommonWEALTH OF NATIONS (1964); SOVIET LEgAL INSTITUTIONS (1962); co-author (with Vladimir Gsovski), Government, LAw AND Courts in the Soviet Union and EAstern Eurote (1959).

1 Belemecich Estate, 411 Pa. 506, 511, 192 A.2d 740, 742 (1963), rev'd per curiam sub nom. Consul Gen. of Yugoslavia v. Pennsylvania, 375 U.S. 395 (1964).

"See cases cited in Chaitkin, The Rights of Residents of Russia and Its Satellites to Share in Estates of American Decedents, 25 So. CAL. L. REv. 297 (1952); Heyman, The Nonresident Alien's Right to Succession Under the "Iron Curtain Rule," 52 Nw. U.L. Rev. 221 (1957); Jones, Iron Curtain Distributees: A Mounting Problem in Pennsylvania's Orphans' Courts, 69 Drck. L. Rev. 227 (1965); Scheller \& Mayda, Payment
} 
have become a focal point for recent criticism by American commentators, most notably Professor Berman ${ }^{3}$ of the Harvard Law School and Professor Ginsburgs ${ }^{4}$ of the University of Iowa.

Both Professors Berman and Ginsburgs reach the fundamental conclusion that American courts have exemplified political bias and motivation when dealing with claims of the nationals of a socialist country to an American estate. Professor Ginsburgs arrives at this position after a detailed examination of Soviet civil law, which, he finds, displays a radical evolution from drastic restrictions tantamount to the elimination of the institution of inheritance to a modern-day progression towards liberalization. ${ }^{5}$ Finding that Soviet law does indeed provide for inheritance by foreigners from Soviet residents, both in theory and in unreported practice, ${ }^{6}$ he proceeds to examine the well-known California decision of Estate of Gogabashvele, in which a California appellate court refused to allow a Soviet heir to receive his share of an estate because the necessary reciprocity required by the California statute ${ }^{8}$ was absent. Professor Ginsburgs concludes that the Gogabashvele decision (and impliedly all others similar to it) is

the most refined amalgam of obvious half-truths, sly innuendoes, crude fabrications, and gross distortions that dedicated narrowmindedness and political bias have combined to produce on this theme. With all the good will, charity, and kindness in the world, one can describe it only as an unholy brew which patent intellectual dishonesty alone could manage to distill. ${ }^{9}$

Professor Berman, on the other hand, relies primarily on his own experience in American courts and his conversations with Soviet lawyers and government officials.10 He cites, for example, the existence of unreported decisions and secret decrees which he has been shown while in the Soviet Union." He concludes that "for

of Estate Shares to Beneficiaries Behind the "Iron Curtain," Wis. Bar Bull., June 1955, p. 17; 7 W. REs. L. REv. 179 (1956).

${ }^{3}$ Berman, Soviet Heirs in American Courts, 62 Colum. L. Rev. 257 (1962).

4 Ginsburgs, Inheritance by Foreigners Under Soviet Law, 51 IowA L. REv. 16 (1965).

- Ginsburgs, supra note 4, at 24-34.

- Id. at 50-59.

7195 Cal. App. 2d 503, 16 Cal. Rptr. 77 (Dist. Ct. App. 1961).

${ }^{8}$ Cal. Prob. Code $\$ 259$.

- Ginsburgs, supra note 4, at 70.

${ }^{10}$ Berman, supra note 3, at 269 \& n.36.

11 Ibid. 
American judicial decisions to withhold distribution of funds in estates to Soviet heirs constitutes a 'discriminatory practice' against Soviet citizens that 'sometimes takes the form of a manifestation of cold war.' "12 While recognizing mitigating factors ${ }^{13}$ he finds that the hatefulness of a foreign country's social, economic, and political system is no justification for depriving its citizens of their right to receive their distributive shares of American estates, or for depriving American citizens of their right to leave their property to whomever they wish. ${ }^{14}$

In conclusion, he says that state statutes

should not be converted into absolute barriers either by imposing upon the foreign claimant an insuperable burden of proof or by insisting that the legal system under which he lives conform to our own ideals. ${ }^{15}$

\section{American Statutes}

Before proceeding further, it is necessary to review briefly the system of inheritance of American estates by heirs residing in communist countries. In many states the foreign heir of an American estate has the same rights of inheritance as a United States citizen.10 A number of states, however, have sought to limit severely this right by statutes which may prevent the transmission of American estates to residents of communist countries.

\section{A. The Two Basic Types}

There are actually two types of statutes. The New York ${ }^{17}$ or "benefit" type ${ }^{18}$ provides that where the beneficiary of an American

12 Id. at 272.

${ }^{13} \mathrm{Yd}$. at $272-73$.

14 Id. at 274.

${ }^{15}$ Ibid.

${ }^{16}$ E.g., TEX. PRob. Code $\$ 41$ (1956).

${ }^{17}$ N.Y. SURR. CT. ACT $\S 269$-a.

${ }^{18}$ Aside from New York, "benefit" statutes are in force in seven other states: FLA. StAT. ANN. \$ 731.28 (2) (1964); MD. ANN. CODE art. 93, § 161 (a) (Supp. 1964); MAss. ANN. LAws ch. 206, § 27A (Supp. 1964); N.J. Stat. ANN. \$ 3A:25-10 (1953); ORE. REv. Stat. $\$ 111.070$ (1) (c) (Supp. 1957); PA. Stat. ANN. tit. 20, § 1156 (Supp. 1965); R.I. GEN. LAWs ANN. \$ 33-13-13 (1956). According to Chaitkin, supra note 2, at 314-15, Michigan, Missouri and Vermont have also adopted the "benefit" theory by local court rules. Maine apparently has adopted the "benefit" test by judicial decision. Berman v. Frendel, 154 Me. 337, 148 A.2d 93 (1959). Illinois and Tennessee, on the other hand, have refused to adopt the benefit test by judicial decision. In the Matter of Estate of Miller, 35 Ill. App. 2d 349, 182 N.E.2d 913 (1962); Hamilton Nat'1 Bank v. Touriansky, 197 Tenn. 245, 271 S.W.2d 1 (1954). 
estate would not have the "benefit" or "use" or "control" of the funds in question, the court should hold them in trust until such time as the beneficiaries will be able to use them. ${ }^{19}$ The second type of provision which has been adopted is the "reciprocity" statute. ${ }^{20}$ Under this test the right of the communist alien to inherit is dependent upon the reciprocal right of a United States citizen to inherit from a decedent in that alien's country on equal terms with resident citizens. The burden of proving such a reciprocal right is upon the claimant legatee, and proof of the foreign law is a matter of fact. ${ }^{21}$ If the claimant fails in his burden and no other heirs are found, the estate escheats to the state. ${ }^{22}$

Several distinctions between the two types of statutes must be made. First, the benefit type does not deprive the alien of his right to inherit. Legally he does inherit the estate, but payment is withheld until he receives the "benefit, use and control" of the funds. The reciprocity statute, however, gives the alien no inheritance rights; rather, the estate immediately escheats. The practical results of both types are the same under present circumstances, but those whose legacies are withheld under the benefit rule conceivably still could take their estates in the foreseeable future. Second, the focus of inquiry into foreign law is different under each statute. The reciprocity statute requires analysis of the foreign law to determine whether a United States citizen can inherit under that law. The benefit rule, on the other hand, logically requires an analysis of the inheritance rights of the citizens of the foreign country in question. If under the law of the foreign country, citizens and aliens have the same inheritance rights, the identical result ensues whether one applies the reciprocity or benefit rule. Courts have sometimes confused the tests, ${ }^{23}$ however, and under

${ }^{10}$ In addition, the statutes of ten states provide that the money will revert to the state after a specified period of time, subject to the right of the beneficiary to reclaim the funds later, without interest. E.g., N.Y. SuRR. CT. Act $\$ 269$-a.

${ }^{20}$ E.g., Gal. Prob. Cone $\S \S 259,259.2$, Cal. Prob. Code $§ 259.1$ (Supp. 1965); Iowa Code ANN. $\$ 567.8$ (Supp. 1964); Mont. Rev. Codes ANN. $\$ 91-520$ (1964); Nev. Rev. STAT. $\S \S 134.230-.250$ (1957); N.C. GEN. STAT. $\S \S 64-3$ to -5 (1965); ORE. REv. Stat. § 111.070 (1) (a) (Supp. 1957).

${ }_{21}$ E.g., Cal. Prob. Code $\$ 259.1$ (Supp. 1965); Iowa Code ANn. § 567.8.2 (Supp. 1964); Mont. Rev. Codes ANN. \$ 91-520.2 (1964); NEv. Rev. STAT. \$ 134.240 (1957); N.C. GEN. STAT. $\$ 64-4$ (1965); ORE. Rev. STAT. $\$ 111.070$ (2) (Supp. 1957).

22 E.g., Gal. PROB. Code $\$$ 259.2; Iowa Code ANN. $\$ 567.8 .3$ (Supp. 1964); Nev. Rev. STAT. \$ 134.250 (1957); N.C. GEN. STAT. \& 64-5 (1965); ORE. REV. STAT. \$ 111.070 (3) (Supp. 1957).

${ }^{33}$ E.g., Estate of Nersisian, 155 Cal. App. 2d 561, 318 P.2d 168 (Dist. Ct. App. 1957), 
the benefit rule have focused not on the foreign law but upon other factors, such as difficulties and costs of transmission, and monetary regnlations. ${ }^{24}$

\section{B. The History Behind the Statutes and Their Judicial Interpretation}

In this country, because of the large immigrant population and resultant family ties with "the old country," questions of inheritance have been of greater importance than elsewhere. These questions usually arise in connection with inheritance of American estates by aliens residing abroad. Initially, the problem was raised in connection with the discriminatory Nazi legislation, the first statutes appearing shortly after the 1938 Munich Agreement. ${ }^{25}$ Although primarily designed to prevent Germany from obtaining control of American assets, numerous cases before World War II applied this restrictive legislation to cases of inheritance devolving on Soviet citizens. ${ }^{28}$ The opposition of American courts to allowing the Soviet government to share in American estates disappeared with the Soviet embroilment in the war on the side of the Western powers. In the case of In re Alexandroff's Estate, ${ }^{27}$ for example, the

in which the lower court seemed to apply a benefit test although the California statute, CAL. Prob. CoDe $\$ 259$, is clearly of the reciprocity type. This led to confusion in lower California courts. E.g., Estate of Anna Smith, No. 124249, Super. Ct., 1960, cited in Estate of Feierman, 202 Cal. App. 2d 552, 555 \& n.1, 20 Cal. Rptr. 883, 885 \& n.1 (Dist. Ct. App. 1962).

2 Most frequently courts have withheld distribution by relying on a Treasury Regulation, 31 C.F.R. \$ 211.2 (a) (1965), discussed infra notes 30-32 and accompanying text. A second device relied upon is the foreign currency exchange rate. Courts have held that the rate of exchange of dollars for the local currency of a communist coun. try is so distorted that the beneficiary reccives only a fractional share of the real value, the remainder being "confiscated" by the state through the currency exchange medium. See Mazurowski, 331 Mass. 33, 38-39, 116 N.E.2d 854, 858 (1954); In the Matter of Dobo, 204 Misc. 975, 980.83, 126 N.Y.S.2d 441, 447-49 (Surr. Ct. 1953). Berman criticizes these cases for using "false criteria" in measuring the exchange value of the dollar in terms of the foreign currency. Berman, supra note 3, at 266.68 \& $n .32$.

${ }^{25}$ See Chaitkin, supra note 2, at 298-302. 1940).

${ }^{28}$ E.g., In the Matter of the Estate of Bold, 173 Misc. 545, 18 N.Y.S.2d 291 (Surr. Ct.

${ }^{27} 61$ N.Y.S.2d 866 (Surr. Ct. 1945). A similar view was expressed by the California court of appeals in Estate of Kennedy, 106 Cal. App. 2d 621, 235 P.2d 837 (Dist. Ct. App. 1951). The court established that Rumania, under Russian domination and with a communist government, had nationalized various kinds of industry and property. It did not believe, however, that these facts were relevant to the issue, because the law of wills, descent, and succession was not affected by the political and economic changes in Rumania, and property other than nationalized property was inheritable.

Both courts overlooked the fact that, although the circle of persons admitted 
court found that Soviet inheritance law had been amended so that all reasons for withholding distribution of American estates to Soviet nationals had been removed. With the advent of the cold war, however, American courts soon resumed their original course. ${ }^{28}$ When the Soviet form of government spread to other countries, nationals of those countries were accorded treatment similar to that given to Soviet citizens. ${ }^{29}$

On February 9, 1951, the Treasury Department, in concurrence with the State Department, suspended transactions involving the payment of monies to nationals of the Soviet Union and her satellites. Although this directive applied only to checks and warrants drawn against funds of the United States, American courts have often found guidance in its provisions for inheritance cases pending before them. Section 211.3 of the regulation suspending payments specifically named Albania, Bulgaria, Czechoslovakia, Estonia, Hungary, Latvia, Lithuania, Poland, Rumania, the Soviet Union, the Russian Zone of Occupation of Germany, and the Russian Sector of Berlin, ${ }^{30}$ and American courts have thus denied relief to residents of those areas. ${ }^{31}$ When other countries were added to the

to privileged inheritance was enlarged by the 1945 Edict of the Federal Presidium of the Soviet Union, that edict still did not remove the limitations to own and therefore bequeath property. See 1 Gsovski, Soviet Civir LAw 555-80, 657-58 (1948).

${ }^{28}$ E.g., In the Matter of Best, 200 Misc. 332, 107 N.Y.S.2d 224 (Surr. Ct. 195I); Sobko Estate, $88 \mathrm{~Pa}$. D. \& C. 76 (Orphans' Ct. 1954).

${ }^{20}$ E.g., Estate of Arbulich, 248 P.2d 179 (Cal. Dist. Ct. App. 1952), aff'd, 41 Cal. 2d 86, 257 P.2d 433, cert. denied, 346 U.S. 897 (1953) (Yugoslavia); Mazurorwski, 33I Mass. 33, 116 N.E.2d 854 (1954) (Poland); In the Matter of Estate of Url, 7 N.J. Super. 455, 71 A.2d 665 (Somerset County Ct.), appeal dismissed, 5 N.J. 507, 76 A.2d 249 (1950) (Hungary); In the Matter of Dobo, 204 Misc. 975, 126 N.Y.S.2d 44I (Surr. Ct. 1953) (Czechoslovakia and Hungary); In re Miller's Will, 115 N.Y.S.2d 255 (Surr. Ct. 1952) (East Germany); In the Matter of Geffen, 199 Misc. 756, 104 N.Y.S.2d 490 (Surr. Ct. 1951) (Lithuania).

${ }^{30} 16$ Fed. Reg. 1818 (1951), as amended, 3I C.F.R. § 211.2 (a) (1965). The regulation now includes Communist China, Cuba, North Korea and North Viet Nam. Poland was omitted from the.1957 list, 22 Fed. Reg. 4134 (1957), Rumania from the 1960 list, 25 Fed. Reg. 3526 (1960), and Bulgaria from the 1964 list, 29 Fed. Reg. 15287 (1964). The current regulation thus reads: "It is hereby determined that postal, transportation, or banking facilities in general or local conditions in Albania, Communistcontrolled China, Cuba, Czechoslovakia, Estonia, Hungary, Latvia, Lithuania, North Korea, North Viet-Nam, the Union of Soviet Socialist Republics, the Russian Zone of Occupation of Germany, and the Russian Sector of Occupation of Berlin, Germany, are such that there is not a reasonable assurance that a payee in those areas will actually receive checks or warrants drawn against funds of the United States, or agencies or instrumentalities thereof, and be able to negotiate the same for full value." 31 C.F.R. § 211.2 (a) (1965).

${ }^{31}$ E.g., Mazurowski, 331 Mass. 33, 116 N.E.2d 854 (1954) (Poland); In the Matter of Dobo, 204 Misc. 975, 126 N.Y.S.2d 441 (Surr. Ct. 1953) (Czechoslovakia and Hungary); In re Rysiakiewicz' Will, 114 N.Y.S.2d 504 (Surr. Ct. 1952) (Poland); In the 
list, the same judicial result ensued. ${ }^{32}$

These state court decisions have, on the one hand, often employed a close analysis of the law of the communist country in question, but have also led to some rather remarkably less than desirable judicial opinions. Justice Musmanno's comment which prefaced this article is but one example. Professor Berman has noted several other instances of judicial prejudging through the use of political bias. ${ }^{33}$

It must also be noted, however, that decisions under these statutes have demonstrated a liberal evolution with respect to the communist nations other than the Soviet Union. For example, the Montana courts have now found the requisite reciprocity with Rumania, ${ }^{34}$ Czechoslovakia, ${ }^{35}$ and Yugoslavia. ${ }^{36}$ Oregon has found reciprocity with Estonia by virtue of a treaty. ${ }^{37}$ Pennsylvania has found the requisite "benefit, use and control" for Polish ${ }^{38}$ and Yugoslav $^{39}$ heirs. The existence of reciprocity with Yugoslavia has been firmly established by the Supreme Court in Kolovrat $v$. Oregon, ${ }^{40}$ in which the Oregon Supreme Court's failure to find reciprocity was reversed on the basis of an 1881 treaty between the United States and Serbia.4 While there are decisions withholding distribution

Matter of Terry, 200 Misc. 543, 107 N.Y.S.2d 225 (Surr. Ct. 1951) (Hungary); In the Matter of Best, 200 Misc. 332, 107 N.Y.S.2d 224 (Surr. Ct. 1951) (Russia); In the Matter of Geffen, 199 Misc. 756, 104 N.Y.S.2d 490 (Surr. Ct. 1951) (Lithuania); State Land Board v. Pekarek, 234 Ore. 74, 378 P.2d 734 (1963) (Czechoslovakia); Liebelt Estate, 13 Fiduc. Rep. 63 (Pa. Orphans' Ct. 1963) (East Germany); Choma Estate, 30 Pa. D. \& C.2d 157 (Orphans' Ct. 1963) (Russia).

${ }^{32}$ E.g., In the Matter of Mulligan, 200 Misc. 499, 107 N.Y.S.2d 221 (Surr. Ct. 1951) (Communist China).

${ }^{33}$ Berman, supra note 3, at 257-58 \& n.3.

34 In the Matter of Estate of Gaspar, 128 Mont. 383, 275 P.2d 656 (1954).

${ }^{35}$ In the Matter of Estate of Hosova, 143 Mont. 74, 387 P.2d 305 (1963).

${ }^{38}$ In the Matter of Estate of Spehar, 140 Mont. 76, 367 P.2d 563 (1961); In the Matter of Estate of Ginn, 136 Mont. 338, 347 P.2d 467 (1959); In the Matter of Estate of Spoya, 129 Mont. 83, 282 P.2d 452 (1955).

${ }^{37}$ In the Matter of Estate of Kasendorf, 222 Ore. 463, 480-81, 353 P.2d 531, 539 (1960).

38 Poplawski Estate, 10 Fiduc. Rep. 503 (Pa. Orphans' Ct. 1960); accord, In the Matter of Estate of Tybus, 28 Misc. 2d 278, 217 N.Y.S.2d 913 (Surr. Ct. 1961).

${ }^{39}$ Aras Estate, 16 Pa. D. \& C.2d 635 (Orphans' Ct. 1959).

${ }^{10} 366$ U.S. 187 (1961), reversing In the Matter of Estate of Stoich, 220 Ore. 448, 349 P.2d 255 (1960). See also Consul Gen. of Yugoslavia v. Pennsylvania, 375 U.S. 395, reversing per curiam Belemecich Estate, 411 Pa. 506, 192 A.2d 740 (1964).

$\$ 1$ Treaty With Serbia for Facilitating and Developing Commercial Relations, Oct. 2/14, 1881, art. II, para. 2, 22 Stat. 963, T.S. No. 319 (effective Dec. 27, 1882) [now in effect with Yugoslavia via Agreement With Yugoslavia Regarding Pecuniary Claims of the United States and Its Nationals, July 19, 1948, art. V, 62 Stat. 2658, T.I.A.S. No. 1803]. 
to these communist nations, ${ }^{42}$ the picture is rapidly changing. Neither Professors Berman nor Ginsburgs takes full cognizance of this evolution, although in all fairness it must be said that they are both primarily concerned with the law in the Soviet Union itself and the cases involving Soviet heirs as distinguished from heirs in other communist nations.

II

\section{Soviet STATUTES}

Since Soviet inheritance law is important to the court's inquiry under either type of statute, it is worthwhile at this point to examine the relevant Soviet provisions.

Where an American benefit statute is involved, it is important to note that the institution of inheritance was ostensibly abolished in the Soviet Union only during a short period after the Revolution. ${ }^{43}$ It was gradually reestablished, and since 1945 has been a part of the Soviet legal system in a form greatly resembling the provisions of the leading civil codes of Europe. ${ }^{44}$

American reciprocity statutes are phrased in terms of requiring equality of treatment of American beneficiaries with Soviet beneficiaries. The evidence which an American court seeks, therefore, is evidence of discrimination or nondiscrimination against aliens in inheritance proceedings in the foreign country. Inequality of treatment between Russian and American beneficiaries could exist in a variety of factual contexts. The two most important situations would be: 1) where the decedent is a Russian citizen, and 2) where the decedent is an alien in the Soviet Union. ${ }^{45}$ Whether there is

42 E.g., Estate of Karban, 118 Cal. App. 2d 240, 257 P.2d 649 (Dist. Ct. App. 1953) (Czechoslovakia); Estate of Arbulich, 248 P.2d 179 (Cal. Dist. Ct. App. 1952), aff'd, 41 Cal. 2d 86, 257 P.2d 433, cert. denied, 346 U.S. 897 (1953) (Yugoslavia); In the Matter of Estate of Draganoff, 43 Misc. 2d 233, 252 N.Y.S.2d 104 (Surr. Ct. 1964) (Bulgaria); In the Matter of Estate of Reidl, 39 Misc. 2d 805, 242 N.Y.S.2d 105 (Surr. C.. 1963) (Czechoslovakia); State Land Board v. Pekarek, 234 Ore. 74, 378 P.2d 734 (1963) (Czechoslovakia); Liebelt Estate, I3 Fiduc. Rep. 63 (Pa. Orphans' Ct. 1963) (East Germany).

${ }^{4}$ See I Gsovski, Soviet Civil Law 623-27 (1948).

"See 2 Gsovskt \& Grzybowski, Government, Law and Courts in the Soviet Union AND EASTERN EURope I163-74 (1959).

4 There are actually six variable factors in each case: 1) residence of decedent, 2) nationality of decedent, 3) place of death of decedent, 4) residence of beneficiary, 5) nationality of beneficiary, and 6) location of property. American reciprocity statutes are principally concerned with the rights of resident citizens of the United States, and hence factors 4 and 5 will be constant. The property in question must be located in the Soviet Union for courts there to have jurisdiction, and hence factor 6 will also be 
discrimination in either situation is a matter not free from doubt.

In the case of the decedent who is an alien in the Soviet Union, no answer could safely be given prior to 1961. No Soviet statute alluded to the problem, and there were no cases involving such a factual setting. ${ }^{46}$ It was clear, however, that the Soviet position was to apply Soviet law to all inheritance cases, even if involving foreign nationals. ${ }^{47}$ This result was achieved by utilizing the national regime doctrine, under which all aspects of the personal status of a resident alien automatically fell under the law of the forum. ${ }^{48}$

The Principles of Civil Legislation of 1961 have shed new light on this problem. Article 122 states that "foreign citizens enjoy in the USSR the same civil law capacity as Soviet citizens,"40 and article 59 provides that "foreign citizens have access to Soviet courts and enjoy equal procedural rights with Soviet citizens." 0 Thus the rights and obligations of aliens in the Soviet Union have been made commensurate with those of Soviet citizens. In addition,

constant. For purposes of discussion in this article, it will be assumed that factor 3 (place of death) is irrelevant.

The remaining possibilities thus consist of a decedent, leaving property in the Soviet Union to an American resident citizen, who is: a) an American citizen residing in Russia, b) an American citizen residing in the United States, c) a Russian citizen residing in Russia, and d) a Russian citizen residing in the United States.

As will be pointed out later in the text, Soviet law today would make no substantive distinction between cases $c$ and $d$. This accounts for the singularity of the situation numbered " 1 " in the text. Case $a$ is the text's situation number "2," Case $b$ properly should constitute a situation number " 3 " in the text, but since such a situa. tion will be comparatively rare, since it might involve other considerations of inter. national law, and since it might be resolved in the same manner as situation " 2 ," it bas been omitted.

${ }^{40}$ See note 54 infra and accompanying text.

47 This position was amplified by the provisions of $\$ 17$ of tbe Foreign Citizens Regulation of August 4, 1922, of the Belorussian government, which put the estates of foreign nationals under the rule of Soviet law. See Uschakow, Die Entwicklung des internationalen Privatrechts und des Aussenhandelsrechts in der Sowjetunion seit Stalins Tod (The Development of International Private Law and Foreign Commerce Law in the Soviet Union Since the Death of Stalin), IV/2 JAHrbuchrür Ostreckr (Yearbook for Eastern Law) 64 (1963).

${ }^{48}$ When Soviet citizens died abroad, Soviet jurists contended that this doctrine restricted jurisdiction of the country of residence in matters of inheritance. They claimed that the legal capacity of Soviet citizens abroad was governed by foreign law but that inheritance was still determined by Soviet law. See Peretersin \& Kry lov, Mezhdunarodnoe Ghastnoe Pravo (International Private Law) $\$ \S 54-55$ (2d ed. 1959). Soviet jurists apparently argued this point in order to justify the elaim that the Soviet state is entitled to inherit estates of Soviet citizens who die abroad leaving no heirs. Id. $\S 55$, at 184 .

40 Principles of Civil Legislation art. 122, [1961] Vedomosti Verkhovnogo Soveta SSSR (Journal of the USSR Supreme Soviet) No. 525 [hereinafter cited as Ved. SSSR].

${ }^{50}$ Principles of Civil Legislation art. 59, [1961] Ved. SSSR No. 525. 
article 127 abandons the national regime doctrine in inheritance cases: "Matters of succession are governed by the law of the country in which the deceased had his last permanent residence."51 Taken together, these provisions seem clearly to indicate a shift in position in Soviet law, establishing definite choice of law rules which recognize the possible application in Soviet courts of foreign law, and treating alien beneficiaries in the Soviet Union on a parity with Soviet beneficiaries. This shift in position would seem to apply equally to alien beneficiaries outside the Soviet Union. The only possible limitation in this latter situation is the technical one of transmission of sums realized from the liquidation of Soviet estates to persons living abroad. Here a resolution of the Council of Ministers of April 21, 1955, comes into play. ${ }^{52}$ This resolution provides an exception to the general provisions of currency controls in the Soviet Union. All that is required for transmission is a certificate of the notary who conducts the probate proceedings stating that the nonresident beneficiary is entitled to a share of the estate. 53

The Principles of Civil Legislation do not expressly answer the question presented by the case of the Soviet citizen who dies and leaves property to a resident of the United States. Here again there is no statute on the topic, and the few cases referred to by Soviet jurists ${ }^{54}$ do not involve decedents of central Russia itself,

\footnotetext{
${ }^{51}$ Principles of Civil Legislation art. 127, [1961] Ved. SSSR No. 525.

52 [1959] Sbornik Prikazov i instruktsii po finansovo-khoziaistvennym voprosam (Collection of Decrees, Orders and Instructions on Financial-Economic Questions) No. 11, p. 35 .

${ }^{3}$ No permit of the Minister of Finance is required.

Transmission also depends on reciprocity, which, however, is considered conclusively proven when the Soviet Union has a treaty with the beneficiary's country. See 2 Lunts, Mezhdunarodnoe Chastnoe Pravo (International Private Law) 279-80 (1959); Volchkov \& Rubanov, Ogorvorka o vzaimnosti $v$ sovetsko-amerikanskikh nasledstvennykh otnosheniiakh (The Reciprocity Requirement in Soviet-American Inheritance Relations), [1960] Sovetskil EzHEgodnIK MEzhdunarodnogo Prava (Soviet Yearbook of International Law) 308. Such treaties are uncommon with Western nations. One example is an exchange of notes between the Soviet and Greek governments in 1956. 17-18 Sbornik Deistvuiushchikh Dogovorov, Soglashchenii i Konventsii, Zakliuchennykh SSSR s Inostrannymi Gosudarstvami (Collection of Treaties, Agreements and Conventions in Force Concluded by the USSR with Foreign Countries) 270-71 [hereinafter cited as S.D.D. USSR].

*t Boguslavskii \& Rubanov, Grazhdansko-protsessual'nye prava inostrantsev v SSSR (Rights of Aliens in Civil Process in the USSR), [1959] SOvETSKII EzHEGonNIK Mezhdunarodnogo Prava 181, 187-88; Cheburakhin, Praktika primeneniia zakonodatel'stva SSSR o grazhdanskoi pravosposobnosti inostrantsev (Judicial Practice in the Application of Russian Legislation on Civil Law Capacity of Foreigners), Sovetskoe Gosudarstvo i Pravo (Soviet State and Law) No. 8, pp. 114-17 (1957); Korobov \&
} 
but rather citizens of territories annexed to the Soviet Union during the course of World War II who leave property to relatives who escaped to the West. The authority of these cases is thus questionable, and the factual setting in which they occur will soon disappear. Nevertheless, the spirit of the Principles, which clearly attempt to make certain concessions to alien beneficiaries, ${ }^{65}$ could indicate that United States citizens will be able to share in estates of Soviet citizens as well as of aliens in the Soviet Union..$^{50}$

\section{III}

\section{Other Considerations}

If either Professor Berman or Professor Ginsburgs were writing this article, it might very well stop at this point. But a comprehensive analysis of the problem should include some further and important considerations.

Sokolov, Imushchestvennye prava inostrantsev $v$ praktike sovetskogo suda $i$ notariata (Property Rights of Aliens in the Practice of Soviet Courts and Notaries), [1961] Sovetskil Ezhegodnik Mezhdunarodnogo Prava 361.

ES Other aspects of the structure of the Principles may be briefly discussed. The key term in article 127 is "permanent residence (postoiannoe mestozhitel'stvo)," which provides the link between the matrix of legal relationships arising from the opening of an estate, and the legal system to be applied to those relationships. To determine residence, a Soviet court must look to Soviet law. According to Soviet writers, however, it is difficult in a concrete case for Soviet law to make such a determination. See LUNTs, op. cit. supra note 53, at 283; Boguslavskii \& Rubanov, supra note 54, at 187.

Article 127 also applies the law of the permanent residence to all questions of testamentary capacity and formal requirements of wills.

In the case of immovables, article 127 provides that Soviet law will govern in all situations.

It is important to realize that article 127 applies only to situations involving the general law of inheritance; if foreign law is found to be applicable, it replaces only this general Soviet law. Two special situations are unaffected: where a kolklioz member dies, his share of its goods is not inheritable; and where a decedent has a savings account, his instructions regarding disposal thereof must be followed.

See generally Grzybowski, Soviet Private International Law 134-40 (Law in Eastern Europe No. 10, 1965).

${ }^{6 B} \mathrm{An}$ interesting question of statutory interpretation may arise under a reciprocity provision. Since most such statutes place the burden of showing reciprocity on the foreign claimant (see note 21 supra), it is possible that such a claimant might be successful in arguing that the Principles establish reciprocity in the case of the alien decedent, but be unsuccessful in arguing reciprocity where a citizen decedent is in. volved. Would an American court then allow distribution to a foreign claimant only where the decedent was an alien in this country and not where he was a citizen? Or must the existence of reciprocity be determined as a whole? If the latter, would the lack of reciprocity in any one situation vitiate the existence of reciprocity in all situations? Cf. Hilton v. Guyot, 159 U.S. 113 (1895).

This decision may also become important when certain types of property are involved. For example, as pointed out in note 55 supra, a decedent's share of kolkhoz property is uninheritable. If an American decedent's property is in some form of joint ownership, should an analogy be drawn and distribution refused? 
First, it must be remembered that to a large degree this is a oneway street. The incidence of cases involving American estates going, or attempting to go, to the communist parts of the world is fairly high. In contrast, cases of estates located in the Soviet Union devolving on foreign nationals abroad are comparatively rare, and their size is rather unimportant. To the purist, this factor may be of no consequence. Nevertheless, since private international law always affects international commerce, it is difficult to cast blame on American judges if this consideration carries some weight in their decisions.

Second, international commerce involving rights of individuals depends on reciprocity and equal treatment of nationals of various countries by courts and government authorities in their mutual relations. This is an old principle, and in international relations represents one of the most important levers of cooperation between nations. In a sense, reciprocity, tested either in its narrower or in its broader conception, is the very essence of legal honesty; it is an ideal in human relations under the rule of law, since it implies equality of rights and of treatment. While it may be expedient to depart from the principle of reciprocity-and international life is full of such measures (e.g., guaranteed prices for products from underdeveloped countries)-departure should be made only in exceptional circumstances. It is fundamental, then, that reciprocity in this broader sense is a permissible criterion for judicial determinations in this area, whether under a benefit statute or reciprocity statute or no statute.

Third, the present line of American judicial decisions represents a part of the reaction of the free societies to the phenomenon of the totalitarian state, with its aggressive social, economic and international policies; it is a reflection of the impact of the totalitarian state upon the position of the individual within its social and economic fabric. Viewed with this in mind, it can be seen that the reaction of the state legislatures and state courts dealing with inheritance rights of nationals of totalitarian states, whether subsumed under the reciprocity or benefit formulas, is organically linked with the condition of the citizen of the communist country at home. The central idea of the long line of decisions of American courts, however unsophisticated the language in which it is expressed, is that inheritance rights of foreign nationals in communist coun- 
tries shall be respected only if their legal position in their home country is broadly similar to that of an individual where the estate lies. Otherwise their rights to property in this country are in fact the rights of the foreign government. 57

All those who are involved in considerations of legal problems touching upon life in a socialist country must be aware of the fact that individual rights represent not only a limited, but also a changing concept. While from time to time socialist countries of the Soviet type experience periods of liberalizing tendencies, they are counterbalanced by periods of reaction and further restriction of individual liberties. Individual life in those countries is shaped by a vast program of social and economic reconstruction, financed at the expense of the standard of living of the broad masses. Indeed, the very concept of private property rights of the Soviet citizen in his country is so drastically restricted that it is hardly comparable to the situation of the individual member of a free society. It must be stressed again that the right to inherit is in the traditional sense a right to benefit the individual himself, not a government or state.

\section{IV}

\section{Property Rights in the Soviet Union}

Let us return briefly to an examination of Soviet law, this time paying more careful attention to broader matters of policy.

In the Soviet Union, and in other communist countries, there is considerable awareness of the real causes of American judicial reluctance to give effect to the claims of communist citizens to shares in American estates. Some socialist countries, such as Poland and Yugoslavia, have taken steps to assure fuller use of American legacies by their inheritors, which in turn has brought about reversal of the attitude of American courts. ${ }^{58}$

But has the Soviet Union taken such steps? We know that from the broad point of view, the Principles of Civil Legislation of 1961 represent a conscious effort by the Soviet government to abandon the policy of insulation of Soviet life from contacts with the out-

\footnotetext{
${ }^{57}$ Cf. Cakste, Das Persönliche Eigentum der Sowjetburger (The Personal Property of the Soviet Citizen), 1 Osteuropa Recht (East Europe Law) 27 (1955).

${ }^{58}$ E.g., In the Matter of Tybus, 28 Misc. 2d 278, 217 N.Y.S.2d 913 (Surr. Ct. 1961); see In the Matter of Estate of Spehar, 140 Mont. 76, 367 P.2d 563 (1961); Poplawski Estate, 10 Fiduc. Rep. 503 (Pa. Orphans' Ct. 1960); Aras Estate, 16 Pa. D. \& C.2d 635 (Orphans' Ct. 1959).
} 
side world. The prior position was detrimental to national interests since, among other things, Soviet citizens were unable to participate in the distribution of foreign estates. As a first step toward the new position the Soviet Union had signed a number of treaties with its eastern satellites which established a uniform method of handling foreign estates. ${ }^{50}$ Similar agreements, though Jess ambitious in scope, had been concluded with other European countries.60 The new policy was also emphasized in Soviet legal periodicals, obviously to familiarize the West with the changing concept of Soviet inheritance legislation. ${ }^{61}$ The Principles of Civil Legislation are the latest step in this "metamorphosis."

This does not answer our question, however. On the positive side, we know also that in the Soviet Union it seemed for a while that the death of Stalin, and the consequent liberalization of the regime, would result in greater respect for individual rights, including the upgrading of the private property institution. Soviet legal periodicals carried a number of articles, written by leading Soviet jurists, which pointed out that respect for individual rights constitutes one of the cornerstones of socialist legality. ${ }^{62}$ Hopes of these jurists were substantiated by the program of vigorous reform of the Soviet legal system. The Principles of Civil Legislation represent a comprehensive attempt to give meaning to the concept of fundamental individual rights.

But there is also a negative side. As the reform of the legal system and of the governmental techniques progressed, the TwentyFirst Congress of the Communist Party of the Soviet Union in 1959 determined to redefine the meaning and to reorient the direction of the legal reform in the Soviet Union. ${ }^{63}$ The Party thought that

${ }^{50}$ The Soviet Union has legal aid agreements with the following socialist countries: Bulgaria (19 S.D.D. USSR 230); Czechoslovakia (19 S.D.D. USSR 384); East Germany (19 S.D.D. USSR 266); Hungary ([1958] Ved. SSSR No. 35); North Korea (19 S.D.D. USSR 294); Poland (20 S.D.D. USSR 329); and Rumania (19 S.D.D. USSR 358).

${ }^{\circ 0}$ The agreement with Greece referred to in note 53 supra is the only clear example. A legal aid agreement with France made in 1936 is still in effect. 9 S.D.D. USSR 85. Consular conventions were concluded with West Germany in 1958 ([1959] Ved. SSSR No. 17/101) and with Austria in 1959 ([1960] Ved. SSSR No. 215).

or See articles cited note 54 supra; Volchkov \& Rubanov, supra note 53.

-2 E.g., Romashkin, Razvitie funktsii sovetskogo gosudarstva $v$ protsesse postroienia kommunizma (Development and Function of the Soviet Government in the Process of Construction of Communism) Sovetskoe Gosudarstvo i Pravo No. 10, p. 9 (1958).

${ }^{03} \mathrm{XXI}$ sjezd kommunisticheskoi partii sovetskogo coiuza o razvitii i ukreplenii 
the time was ripe to link the issue of reform with the question of the transition of the Soviet state from socialism to communism. The socialist state which followed the destruction of the capitalist order, said the Congress, retained certain characteristics of the bourgeois state, which were indispensable under socialism. Among these were remnants of the bourgeois law, including techniques of legal action and the use of force by the state. One of the aims of the reform was to assure a higher degree of equality for all members of the Soviet polity, in particular in the field of property relations. As a commentator explained:

The building of communism, transforming all aspects of social and personal life on a higher social basis, also introduces substantial changes in the problem of personal property. The establishment of communism is the objective basis for the intensification of tendencies toward complete equality on the basis of material and spiritual wealth. ${ }^{84}$

Socialism, as the first condition of human equality, was claimed by Soviet scholars to be achieved by monopolizing the means of production (socialist property) in the hands of the Soviet state. This left considerable inequality in the category of consumer goods (personal property), because the state of the national economy was such that equal satisfaction of everyone's needs was impossible. Communism, it is argued, will eventually remove this last aspect of inequality by increasing the ability of special institutions to meet individual needs beyond bare existence. This increasing ability of social production to satisfy the needs of society will eventually result in fundamental revision of the concept of property.

To reach this new dimension of equality, a new attitude and a new legal basis regarding the use of the so-called durable consumer goods must be created. Under socialism, those who contributed more to social life earned higher incomes, and hence were able to acquire legally a greater share of durable consumer goods-private homes, cars, pleasure boats, and so forth-than the rest of society. This attitude and legal form, expressed in the concept of personal ownership, was proper so long as these goods were in short supply. Now that production of them is assuming mass proportions, how-

sovetskogo sotsialisticheskogo gosudarsta (Twenty-First Congress of the Communist Party of the Soviet Union on the Development and Strengthening of the Soviet Socialist State) (1959).

of Stepanyan, Kommunizm $i$ sobstuennost (Communism and Property), Oktiabr (October) No. 9, p. 16 (1960). 
ever, personal ownership is no longer the correct solution. Rather, the ideal situation is to establish a system where the use of these goods is made available to the public without becoming the personal property of the individuals. ${ }^{65}$

At the present moment, economic conditions in the Soviet Union and the prosperity of the Soviet society are such that there is little immediate danger that these views will result in the transformation of the institutions of property into this higher degree of equality. Nevertheless, Soviet government and party leadership have already begun to experiment with the institution of personal property, thus meriting inquiry into the question of the equality of property relations between the Soviet citizen and the member of a free society.

\section{A New Development}

The most graphic examples for our purposes of a possibly emerging Soviet attitude toward personal property are two recent decrees concerned with the uncompensated confiscation of certain types of property. These decrees are in direct conflict with the Principles of Civil Legislation of 1961. Article 31 of the Principles states that:

The seizure of an owner's property in the interests of the State or public, accompanied by payment to him of its value (requisition), and the seizure without compensation of property by the State as a form of sanction for breach of the law (confiscation) are permitted only in the instance and following the procedure set out in the legislation of the USSR and Union Republics. ${ }^{66}$

Nevertheless, on July 26, 1962, a decree of the Presidium of the Supreme Soviet provided for the uncompensated expropriation of houses, cottages, and other structures built or acquired by citizens with unearned income, or as a result of illegal use of means of government enterprises, establishments, collective farms, and other cooperative and social organizations. ${ }^{67}$ Such structures were to be transferred to the ownership of the communal housing fund of the local authorities, to the kolkhozes and other cooperative and social institutions. A similar decree passed in September of 1963 by the Presidium of the Supreme Soviet of the RSFSR, the largest Soviet

\footnotetext{
${ }^{\circ 5}$ See Grzxbowski, Soviet Legal Institutions 264-66 (1962).

00 Principles of Civil Legislation art. 31, [1961] Ved. SSSR No. 525.

${ }^{\circ 7}$ [1962] Ved. SSSR No. 16.
} 
republic, provided that in proceedings for the expropriation of structures acquired with unearned income, a court may also command confiscation of automobiles acquired in a similar manner. ${ }^{08}$

The two decrees were introduced in other Soviet republics and vigorously enforced. ${ }^{69}$ These enforcement cases indicate that a substantive change is taking place with respect to the concepts of ownership and personal property rights, linking them directly to socially useful employment and the earnings directly connected therewith. According to the opinion of a Soviet jurist:

The problem arises as regards the feasibility of the expropriation of houses . . . acquired or constructed on unearned income from the citizens who have become their owners as heirs, by contract of gift, sale and purchase and by other methods. As the statute does not recognize the right of ownership of structures in persons, who have acquired them with unearned income, it must be recognized that those persons, who have acquired these structures as inheritance or gift, may also be deprived of the right of property in those structures. ${ }^{70}$

A full examination of this development is obviously outside the scope of the present article, and a full analysis of this downward trend in property relations in the Soviet Union is available to the American reader elsewhere. ${ }^{71}$ For present purposes it is enough to point out the obvious fact that the two decrees have established a new form of expropriation proceedings, in addition to expropriation for public needs and confiscation incidental to criminal conviction. The most important immediate consequence of the two decrees is its revolutionary alteration of the property regime in the Soviet Union, in conflict with the system of private rights established by the new civil law and the public order of the Soviet Union guaranteed by the provision of the current constitution. ${ }^{72}$ This in turn has importance for us in two respects.

\footnotetext{
${ }^{88}$ See Sovetskaia Iustitsiia (Soviet Justice) No. 17, p. 7 (1963).

${ }^{\circ}$ See Bloembergen, Personal Property: Downward Trends, Problems of Communism, March-April 1965, p. 42, at 45-46.

${ }_{70}$ Mironov, Voprosy primienienia zakona o bezvosmestnom izniatii stroienii priobretennikh na netrudovye dokhody (The Problem of Application of the Law on Uncompensated Confiscation of Structures Acquired on Unearned Income), Sovetskaia Iustitsiia No. 24, p. 6 (1962). (Emphasis added.) Cf. Mironov, Iz praktiki bezvostmiestnogo izniatia stroienii vozvedennikh ili priobretennikh grazhdanami na netrudouye dokhody (Concerning the Practice of Uncompensated Confiscation of Structures Built or Acquired by Citizens on Unearned Income), Sovetskaia Iustitsiia No. 7, pp. 6.8 (1964).

${ }^{71}$ E.g., Bloembergen, supra note 69 .

72 U.S.S.R. CONST. 1936, art. 10.
} 
In the first place, the two decrees point to the fluidity of property relations in the Soviet Union. Contrary to what Professors Berman and Ginsburgs would want us to believe, private property rights in the Soviet Union are not stable institutions, and this affects vitally the scope and function of the institution of inheritance rights of Soviet nationals and foreigners alike.

In the second place, the old problem of the purpose of recognition of inheritance rights in a foreign country is raised again in a new context. It may be contrary to the public policy of a free society to distribute shares from estates lying in their territory to foreign citizens who have no right to property acquired on unearned income. While the two decrees presently in force apply only to houses and automobiles, it is reasonable to assume that further extensions will occur; and even under the present decrees, the removal of these two items from the permissible uses to which funds transmitted to communist citizens can be put raises serious doubts as to the existence of equality of property rights.

In the broadest perspective, then, contrary again to what the American legal profession is being told, the issue is not so much the improper attitude of American courts and judges who are inclined to rely on opinions of ill-informed experts; quite apart from the legal ability of the two competing expert witnesses in the Gogabashvele case, ${ }^{73}$ the basic issue concerns the fact that social policy affects property relations in the Soviet Union. In this respect, the Soviet regime seems unwilling for reasons of its own internal policy to adopt a position which would inspire confidence in its foreign partners in international legal commerce. Professor Lunts, the foremost Soviet authority in the field of conflicts, has admitted that

international legal commerce of the Soviet Union with other countries as expressed in the institution of private international law enacted in Soviet statutes or agreed to in international agreements with other countries, is determined by its attitude to problems of international cooperation. ${ }^{74}$

In other words, the Soviet government feels no compelling reason to stabilize its property relations to meet the requirements of the benefit or reciprocity legislation of the American states.

${ }^{73} 195$ Cal. App. 2d 503, 16 Cal. Rptr. 77 (Dist. Ct. App. 1961). Professor Berman and Dr. Gsovski were the primary expert witnesses for the two competing parties in this case.

${ }^{24}$ I LunTs, op. cit. supra note 53 , at 3. 


\section{ConcLusion}

In final analysis, the present unhappy situation with regard to claims of Soviet citizens to American estates cannot be wholly attributed to the prejudice and political bias of American courts and judges. Where confronted with the clear legal issue of reciprocity in the form of an international treaty, for example, American courts now generally recognize their duty to honor the public policy of the United States government. ${ }^{75}$ Likewise, American courts have decided that where a communist government makes arrangements which as nearly as possible give its nationals the benefit of their shares in American estates, distribution to them should be allowed..$^{70}$ In the case of the Soviet Union, however, so long as its government follows a policy which is contrary to the clear public policy of this country, an American court may be justified in refusing to distribute funds from American estates to its citizens, under either a benefit or reciprocity statute.

\footnotetext{
${ }^{75}$ E.g., In the Matter of Estate of Spehar, 140 Mont. 76, 367 P.2d 563 (1961); In the Matter of Estate of Kasendorf, 222 Ore. 463, 353 P.2d 531 (1960). While some state courts still will not honor treaties, it is now probable that such decisions will be reversed by the Supreme Court. E.g., Belemecich Estate, 411 Pa. 506, 511, 192 A.2d 740, 743 (1963), rev'd per curiam sub nom. Consul Gen. of Yugoslavia v. Pennsylvania, 375 U.S. 395 (1964); Estate of Stoich, 220 Ore. 448, 349 P.2d 255 (1960), rev'd sub nom. Kolovrat v. Oregon, 366 U.S. 187 (1961). Contra, Estate of Eng, 228 Cal. App. 2d 160, 39 Cal. Rptr. 254 (1964), cert. denied, 381 U.S. 902 (1965).

${ }^{76}$ E.g., In the Matter of Tybus, 28 Misc. 2d 278, 217 N.Y.S.2d 913 (Surr. Ct. 1961); see In the Matter of Estate of Spehar, 140 Mont. 76, 367 P.2d 563 (1961); Poplawski Estate, 10 Fiduc. Rep. 503 (Pa. Orphans' Ct. 1960); Aras Estate, 16 Pa. D. \& C.2d 635 (Orphans' Ct. 1959).
} 